\title{
Vinification and Enology, Based on Competencies
}

\author{
Claudio Fredes Monsalve
}

This book summarizes the competencies of a wine cellar supervisor's job, based on its egress profile. The learning outcomes and global competencies for the supervisor formation process define the performance criteria for five units of competency (UC): 1) manage the crop harvesting and white and red grape receiving 2) manage the white and red fermentation; 3) manage oak handling, clarification and filtration activities; 4) control the bottling process; and the transversal competency, 5) control the food safety, quality assurance, record information, occupational health and safety and environmental requirements. The book begins doing a state of the art for competencybased education for the wine industry in Chile, discusses the definition of the egress profile, and explains each UC. At the beginning of each UC, the work context and the performance criteria are displayed; thereafter, the knowledge is developed through questions and answers and finally, and each competency is demonstrated by pertinent photos and assessment criteria for the three knowledge dimensions (to be, to make and to know). Text synchronized with competency based teaching must be applied to secondary and tertiary education. The book is written for vocational education students and middle level winery managers who must comprehend how to be more competent through practical skills, and for university students who must apply theory to practice.

Vinificación y Enología, basadas en competencias. Un manual para estudiantes y profesores de Educación Técnica, sobre el trabajo competente en bodegas de vino Claudio Fredes Monsalve

Editorial: Universidad Católica del Maule Colección Tabor $\mathrm{N}^{\circ} 25$

Talca, Chile

ISBN: No 978-956-7576-45-6

150 pages, photos

Date of Publishing: January, 2010

Available at: Centro de Extensión UC Maule, Talca

E-mail: extension@ucm.cl,cfredes@ucm.cl

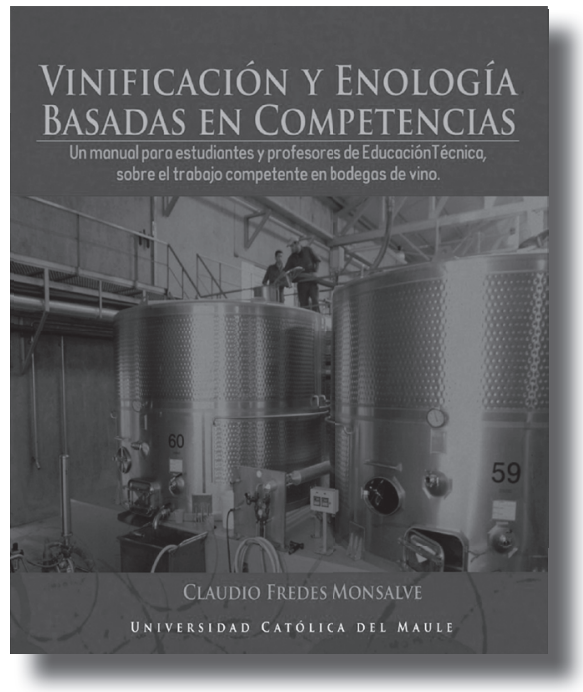

